\title{
KELEMBAGAAN GAPOKTAN MANGGIS DALAM MENGHADAPI PASAR MEA
}

\section{ANNE CHARINA ${ }^{1)}$, RANI ANDRIANI BUDI KUSUMO ${ }^{1)}$ GEMA WIBAWA MUKTI ${ }^{1)}$}

\author{
1) Program Studi Agribisnis Fakultas Pertanian Universitas Padjajdjaran, \\ Jatinangor Sumedang 45363. \\ email : anne.sosek@gmail.com
}

\begin{abstract}
MEA market is a great opportunity for our farmers. One commodity that is likely to be competitive in the MEA market is mangosteen. In fact, various problems faced by Gapoktan to plunge into the free market MEA. This study tried to assess the problems faced by Gapoktan Arta Mukti in the face of the MEA market and looking for problem-solving strategies faced. The method used is descriptive survey, with respondents 30 members Gapoktan Arta Mukti. Soft Systems Methodology used to analyze the problem and produce a conceptual model Gapoktan institutional improvement. The results showed there were many constraints faced by farmers' groups in the face of the MEA level of motivation among farmers to compete in the MEA is still lacking, the availability of ICT is not yet supporting, international networking has not been formed. But on the other hand the farmer has a carrying capacity of which has been certified organic and GHP as an important factor in commodity Manggis a prerequisite for entry into the free market. To prepare gapoktan jump directly to the required socialization MEA MEA, Quality Supervision, ICT Applications and Preparation of international networks.
\end{abstract}

Keyword: Gapoktan, Mangosteen, MEA

\section{PENDAHULUAN}

Hortikultura merupakan komoditas potensial yang mampu bersaing di pasar bebas. Data menunjukkan tingkat permintaan konsumen luar negeri terhadap komoditas horti masih menduduki peringkat atas penyumbang devisa terbesar di Indonesia. Dari sekian banyak horti di Indonesia, Manggis merupakan salah satu komoditas horti yang memiliki kontribusi sangat besar bagi perekonomian kita.

Total Volume eksport komoditas manggis mengalami kenaikan yang signifikan.Pada tahun 2010 Indonesia berhasil mengeksport manggis sebanyak 10.100 ton, meningkat menjadi 20.169 ton di tahun 2012.Sayangnya di tahun 2013 jumlah eksport manggis menurun menjadi 7.646 ton. Penurunan tersebut diakibatkan adanya hambatan tingginya biaya transportasi untuk pemasaran ke luar negeri diikuti dengan tidak stabilnya nilai tukar rupiah. Meskipun terjadi penurunan, permintaan luar negeri terhadap manggis Indonesia tetap tinggi karena kualitas manggis Indonesia termasuk baik dan disenangi oleh pasar luar negeri terutama Thailand dan China (Wijaya, 2000).

Menurut Dinas Pertanian Tanaman Pangan dan Hortikultura (2013), banyaknya permintaan manggis dunia hanya $15 \%$ yang terpenuhi sehingga menjadi peluang untuk para petani manggis untuk lebih mengembangkan 
usahatani manggisnya dengan meningkatkan produksi untuk meningkatkan pendapatan petani manggis.

Gapoktan Arta Mukti adalah salah satu Gapoktan yang tergabung dalam yang semenjak tahun 2008 telah menjadi pemasok tetap manggis ke eksportir PT.Alamanda. Sampai saat ini Gapoktan Arta Mukti sayangnya belum dapat terjun langsung ke pasar MEA karena keterbatasan yang dimiliki, dimana salah satu permasalahan mendasar yang dimilikinya adalah dari internal kelembagaan mereka sendiri. Dengan tidak terjun langsung tapi hanya sebatas sebagai pemasok, anggota Gapoktan merasa bahwa mereka tidak mendapatkan benefit dari adanya pasar bebas ini.

Tabel 1. Luas lahan, Jumlah Pohon dan Produksi Manggis Gapoktan Arta Mukti

\begin{tabular}{lcccc}
\hline $\begin{array}{l}\text { Nama } \\
\text { Gapoktan }\end{array}$ & $\begin{array}{c}\text { Luas Lahan } \\
\text { Manggis }\end{array}$ & $\begin{array}{c}\text { Jumlah } \\
\text { Pohon }\end{array}$ & $\begin{array}{c}\text { Produksi } \\
\text { (Kw) }\end{array}$ & $\begin{array}{c}\text { Produktivitas } \\
\text { (Kw/Pohon) }\end{array}$ \\
\hline Saripuspa & $27 \mathrm{Ha}$ & 1000 & 11.700 & 11,7 \\
Harapan Jaya & $25 \mathrm{Ha}$ & 820 & 8.300 & 10,12 \\
Famili & $40 \mathrm{Ha}$ & 860 & 8.900 & 10,34 \\
Kencana Mekar & $25 \mathrm{Ha}$ & 840 & 8.500 & 10,11 \\
Margahayu & $35 \mathrm{Ha}$ & 900 & 9.400 & 10,44 \\
Pawitan & $45 \mathrm{Ha}$ & 1000 & 11.000 & 11 \\
Sinar Mustika & $40 \mathrm{Ha}$ & 860 & 8.200 & 9,53 \\
\hline Total & $\mathbf{2 3 7 ~ H a}$ & $\mathbf{6 2 8 0}$ & $\mathbf{6 6 . 0 0 0}$ & $\mathbf{7 3 , 2 4}$ \\
\hline
\end{tabular}

Sumber : Data Gapoktan Arta Mukti (2015)

Dari table diatas terlihat produksi manggis di Gapoktan Arta Mukti ukup tinggi dengan luasan lahan yang besar.Ini menjadi potensi yang besar bagi gapoktan untuk maju di pasar MEA.

Penelitian ini akan mengkaji kendala apa yang dihadapi Gapoktan Arta Mukti dalam menghadapi pasar bebas MEA serta mencari strategi penguatan kelembagaan Gapoktan dalam menghadapi MEA (Masyarakat Ekonomi Asean)

\section{METODE PENELITIAN}

Objek penelitian ini adalah strategi penguatan kelembagaan Gapoktan Arta Mukti dalam menghadapi MEA (Masyarakat Ekonomi Asean).Penelitian dilakukan di Gapoktan Arta Mukti, yang berlokasi di Keamatan. Puspahiang, Kab.Tasikmalaya. Pemilihan tempat penelitian tersebut didasarkan atas pertimbangan Gapoktan Arta Mukti merupakan salah satu gapoktan yang menjadi pemasok manggis ke eksportir yang terlibat dalam MEA (Masyarakat Ekonomi Asean) .

Metode yang digunakan adalah survey deskriptif, dengan responden 30 orang anggota GapoktanManggis.Soft System Methodologydigunakan untuk menganalisis masalah dan menghasilkan suatu model konseptual penguatan Gapoktandalam menghadapi perdagangan bebas MEA Alasan peneliti memilih Soft systems methodology (SSM) sebagai rancangan analisis data merupakan sebuah pendekatan untuk memecahkan situasi masalah kompleks yang tidak terstruktur berdasarkan analisis holistic dan berpikir system.SSM adalah sebuah metodologi yang cocok untuk membantu suatu organisasi dalam menjelaskan tujuan mereka dan kemudian merancang sistem aktivitas manusia untuk mencapai tujuan tersebut. 


\section{HASIL DAN PEMBAHASAN}

\section{Kendala Gapoktan dalam menghadapi MEA}

Mengacu pada SSM sebagai tools yang digunakan, maka tahapan pertama yang dikerjakan adalah mendefinisikan situasi keadaan yang muncul di Gapoktan Arta Mukti yaitu Kinerja Gapoktan yang masih relatif lemah. Secara sosialekonomi dan budaya, para futurolog mengatakan bahwa menghadapi persaingan yang semakin ketat dan permasalahan sosial, ekonomi, teknis, dan kelembagaan yang semakin kompleks kedepan, jelas tidak dapat diselesaikan secara perorangan, tetapi perlu dengan kekuatan kelembagaan yang disertai kekuatan hukumnya.

Tahapan kedua adalah tahapan rich picture.Berikut rich picture untuk kondisi di Gapoktan Arta Mukti.

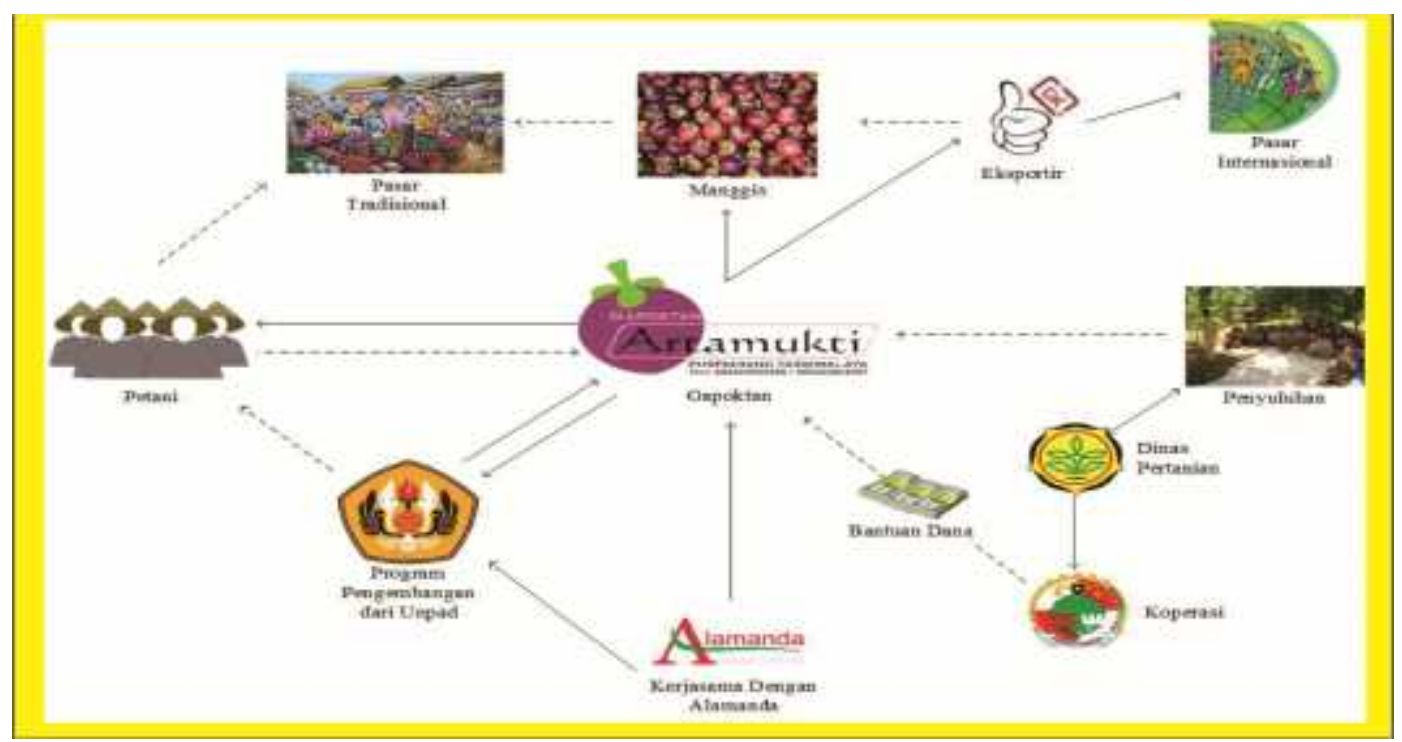

Sumber: Data Olahan, 2016

\section{Gambar 1. Rich Picture}

Dari rich picture terlihat kondisi Gapoktan Arta Mukti Sebenarnya Gapoktan Arta Mukti memiliki peluang yang kuat untuk masuk ke pasar MEA. Dari sisi kualitas dan kuantitas produk, Manggis yang dihasilkan oleh mereka mampu diterima dan memenuhi standar untuk barang eksport.Sejauh ini mereka memasok ke eksportir Alamanda, dan produk mereka banyak diminati oleh konsumen di luar negeri.Dari sisi bentuk, ukuran dan warna meskipun masih ada yang tidak seragam tapi secara keseluruhan dapat dikategorikan baik. Sehingga sebenarnya kans mereka untuk bisa memasok langsung ke pasar MEA terbuka lebar.

Gapoktan Arta Mukti memiliki peluang besar untuk terjun langsung menghadapi MEA (Masyarakat Ekonomi Asean), mereka telahmemiliki sertifikat gudang untuk penyimpanan produk, kemudian sertifikat prima 3 untuk kualitas produk yang dihasilkan. Sayangnya hal tersebut tidak didukung dengan kemampuan pemanfaatkan TIK untuk promosi.Penggunaan TIK seperti Website kelompok, leafleat belum dimiliki oleh Gapoktan.Disamping itu mayoritas petani manggis yang berumur tua juga memiliki motivasi yang rendah untuk ikut bersaing di pasar bebas MEA.Hal ini yang membuat poktan tidak mampu untuk terjun langsung ke pasar MEA. 
Tabel 2. Analisis Catwoe

\begin{tabular}{lll}
\hline 1 & Customer $(\mathrm{C})$ & $\begin{array}{l}\text { Anggota Gapoktan Arta Mukti, Dinas } \\
\text { Terkait } \\
\text { Gapoktan Arta Mukti }\end{array}$ \\
2 & Actors $(\mathrm{A})$ & $\begin{array}{l}\text { Penguatan kelembagaan Gapoktan Arta } \\
\text { Mukti dalam menghadapi MEA } \\
\text { Transformations }(\mathrm{T})\end{array}$ \\
& Wemperbaiki keadaan didalam kelompok \\
& & $\begin{array}{l}\text { Secara internal terlebih dahulu terutama } \\
\text { motivasi anggota, serta perbaikan TIK untuk } \\
\text { mempersiapkan masuk ke pasar MEA }\end{array}$ \\
& Owners $(\mathrm{O})$ & Gapoktan Arta Mukti, Dinas Terkait \\
5 & Environment $(\mathrm{E})$ & Pemahaman terhadap langkah - langkah \\
& yang di lakukan dalam Penguatan Gapoktan
\end{tabular}

Sumber: Data Olahan, 2016

Setelah melewati tahapan analisis Catwoe, langkah selanjutnya adalah Model konseptual sistem yang dideskripsikan dalam definisi awal

Tabel 3. Model Konseptual

\begin{tabular}{|c|c|c|}
\hline No & Aspek & Formulasi \\
\hline 1 & Efficacy & $\begin{array}{l}\text { Penguatan kelembagaan gapoktan secara internal } \\
\text { untuk menghadapi MEA }\end{array}$ \\
\hline 2 & Efficiency & $\begin{array}{l}\text { Partisipasi,Motivasi dari setiap anggota dan pihak } \\
\text { pemerintah, serta penggunaan TIK } \\
\text { keberhasilan poktan }\end{array}$ \\
\hline 3 & Effectiveness & $\begin{array}{l}\text { Keberlanjutan pembinaan dari pihak untuk } \\
\text { meningkatkan partisipasi } \\
\text { kelembagaan poktan }\end{array}$ \\
\hline
\end{tabular}

Sumber: Data Olahan, 2016

\section{Strategi Penguatan Kelembagaan Gapoktan dalam menghadapi MEA}

Perbandingan antara model dan dunia nyata dilakukan untuk mengetahui proses yang terjadi di dunia nyata dan model yang telah disusun. Berikut gambar perbandingan dunia nyata dengan model yang disusun 
REAL WORLD

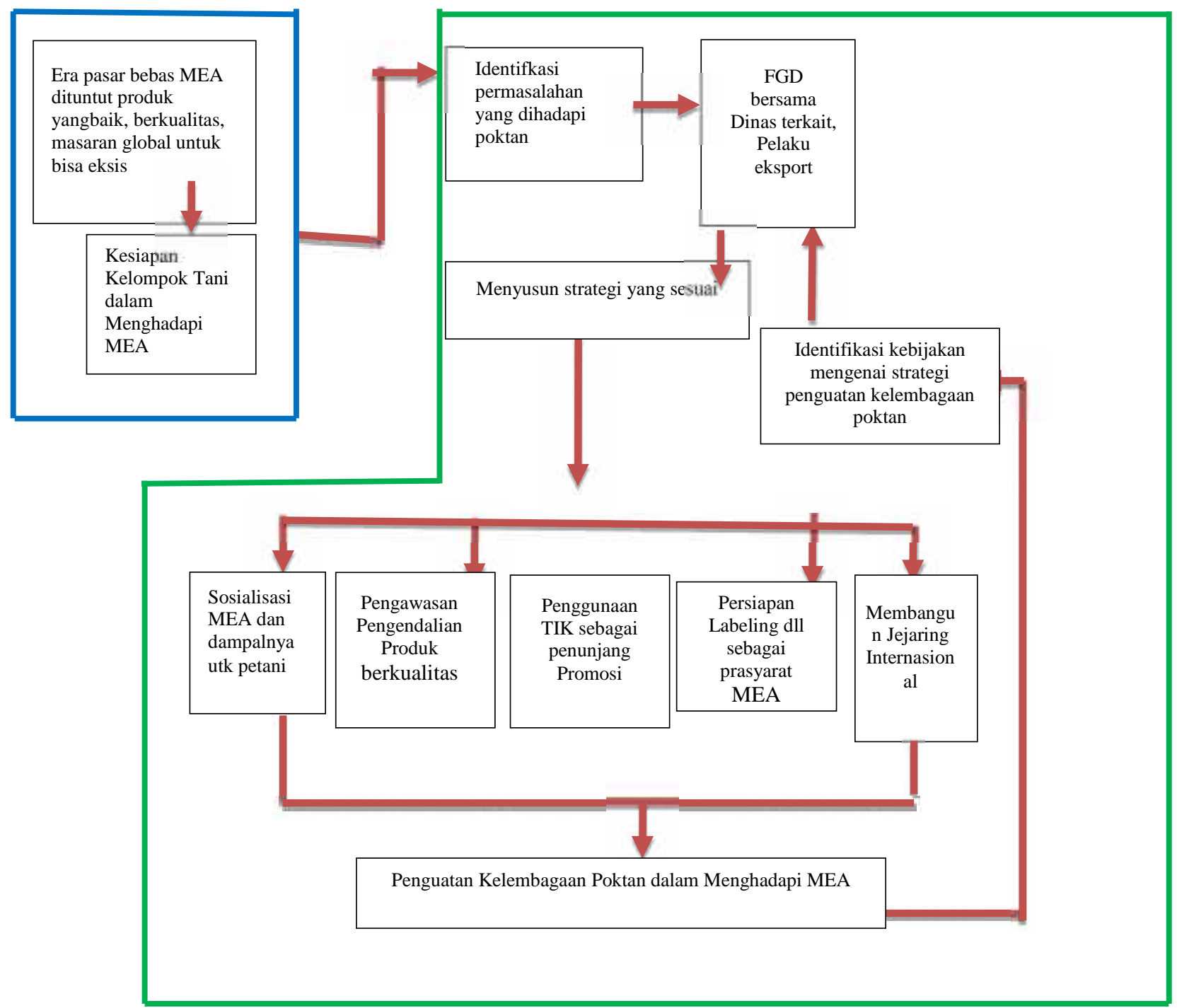

Gambar 2. Model Konseptual Penguatan Kelembagaan Poktan dalam Menghadapi MEA

Berdasarkan model diatas maka strategi penguatan kelembagaan yang harus dilakukan adalah:

1. Sosialisasi MEA dan dampaknya untuk petani. Motivasi petani rendah untuk terjun ke MEA dilandasi pemahaman mereka yang kurang tentang MEA. Untuk meningkatkan motivasidiperlukan sosialisasi pemahaman MEA serta dampaknya untuk kesejahteraan petani

2. Regenerasi petani manggis perlu disiapkan, karena petani manggis saat ini didominasi petani tua. Sehingga keinginan untuk bersaing di pasar MEA tidak ada.

3. Penggunaan TIK sebagai penunjang promosi. TIK yang harus segera dimiliki diantaranya web site Gapoktan, leaflet atau brosur

4. Membangun Jejaring pasar Internasional. Dinas terkait hendaknya memfasilitasi untuk menciptakan dan membangun jejaring kelompok dengan pelaku pasar bebas 


\section{KESIMPULAN}

Kendala yang dihadapi Gapoktan dalam menghadapi MEA diantaranya Tingkat motivasi petani untuk bersaing dalam MEArendah karena petani manggis didominasi umur tua, ketersediaan TIK yang belum menunjang, serta jejaring internasional belum terbentuk. Akan tetapi di sisi lain petani memiliki daya dukung diantaranya telah memiliki sertifikat organic dan GHP sebagai factor penting prasyarat komoditas Manggis untuk masuk ke pasar bebas. Untuk mempersiapkan gapoktan terjun langsung ke MEA diperlukan Sosialisasi MEA, Pengawasan Kualitas, Penerapan TIK dan Persiapan jejaring internasional.

\section{DAFTAR PUSTAKA}

Badan Pusat Statistik. 2014. Produksi Manggis di Indonesia 2010-2014. Melalui (www.bps.go.id, 14 januari 2016)

Bagian Hortikultura. 2013. Produksi Manggis Jawa Barat.Dinas Pertanian dan Tanaman Pangan Jawa Barat. Bandung.

Bagian Hortikultura. 2013. Sentra Produksi Manggis Jawa Barat. Dinas Pertanian dan Tanaman Pangan Jawa Barat. Bandung.

Balai Penyuluh Pertanian, Perikanan dan Kehutanan. 2013. Produksi Manggis di Kecamatan Puspahiang. Kecamatan Puspahiang.

Checkland, P. \& Holwell, S. (1998). Information, Systems and Information Systems - making sense of the field. Chichester: John Wiley \& Sons Ltd.

Dinas Pertanian Tanaman Pangan dan Hortikultura Jawa Barat. 2011.

"P endahuluan Komoditas U nggulan M anggis". Melalui http://diperta.jabarprov.go.id/indeks.php/subMenu/1429, 16 Januari 2016)

Dinas Pertanian Tanaman Pangan dan Hortikultura. 2013. Persentase Ekspor Impor Manggis. Dinas Pertanian Tanaman Pangan dan Hortikultura Kabupaten Tasikmalaya.Tasikmalaya. 